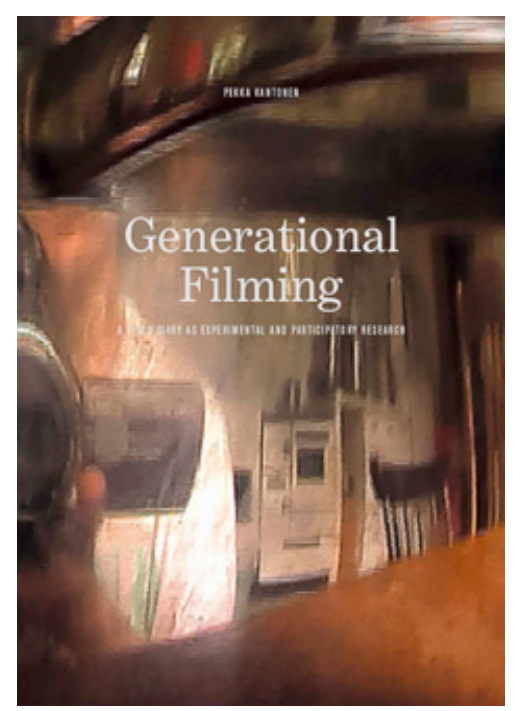

\section{VIDEO JA KATSOJA REFLEKSIIVISESSÄ LIIKKEESSÄ}

\author{
Pekka Kantonen (2017) Generational Filming. A Video Diary as \\ Experimental and Participatory Research. Taideyliopisto. 442 sivua.
}

Pekka Kantonen tuo yhteisöllisen näkökulman videon tekemiseen ja katsomiseen kuvataiteen väitöskirjassaan. Kantosen kehittämän videokuvan sukupolvittelu (generational filming) -metodin tavoitteena on reflektoida videokuvaa ja katsomisprosessia yhteisöllisissä katsomisen tilanteissa. Väitöskirja käsittelee metodin syntyä ja sen käyttöä useissa videokuvaa hyödyntävissä projekteissa. Kantonen sijoittaa tutkimuksensa taiteellisen tutkimuksen, yhteisötaiteen, elokuvatutkimuksen ja etnografian kentille. Elokuvatutkimuksen näkökulmasta väitöskirja on kiinnostava ja kriittinen lisäys erityisesti katsojuutta koskeviin keskusteluihin. Taiteen ja tieteen rajapinnoilla liikkuvassa tutkimuksessa on vahva itserefleksiivinen ote, sillä tutkimuksen kohteena on Kantosen oma taiteellinen tuotanto.

Pitkän linjan tutkija-taiteilija Kantonen kuvaa taidettaan ensisijaisesti yhteisölliseksi ja kertoo sen juurten olevan eri maihin sijoittuvissa "solidaarisuusprojekteissa", joita hän on tehnyt yhdessä puolisonsa Lea Kantosen kanssa. Tutkimuksen aineistona on Kantosen perheen arkea kuvaava videopäiväkirja, jota Pekka Kantonen on kuvannut vuodesta 1990 alkaen. Kotivideomateriaalista on koostettu viisi tapaustutkimusta, jotka esiintyvät tutkimuksessa nimillä The Dream and Blueberry Soup, Spying and Counterspying, Hot Soup, Scolding ja The Haircut. Niiden työstäminen videokuvan sukupolvittelu -metodin avulla käynnistyi vuonna 2005, mutta alkuperäinen materiaali oli siis kuvattu jo aiemmin. Lisäksi aineistona on kolme erityylistä etnografista videota.
Tunúwame liittyy Meksikon alkuperäiskansojen yhteisöprojektiin, jonka tavoitteena on museoverkoston luominen wirrarika-kansalle. Tunúwamen työstäminen jatkuu siis edelleen. Sääti meile Säksä aigu käsittelee Viron Setumaan maakunnassa sekä Venäjällä elävien virolaisten ryhmän, setukaisten, naiskuoron esitystä ja Autobiography of a Friend - Artist in Service ystävätaiteilijan kesänviettoa Turun saaristossa. Videokuvan sukupolvittelu -metodia sovelletaan kaikkiin näihin teoksiin, joita voi yhteisesti nimittää etnografisiksi. Kirja dokumentoi myös väitöksen taiteellisen osuuden, Kodin väreilyä -näyttelyn (2011), joka koostui pääosin samojen tapaustutkimusten pohjalta työstetyistä installaatioista.

\section{Metodin synty}

Suurimman aineiston muodostavat siis kotivideot. Kantonen kuvasi joka päivä yhden oton perheensä arjesta. Tässä tutkimuksessa Kantonen määrittelee videopäiväkirjan kotivideogenren laajennukseksi ja kritiikiksi. Videot eivät kuvaa perinteiseen tapaan syntymäpäiviä ja muita elämän kohokohtia, vaan näennäisen miettimättä valittuja arjen tilanteita. Väitöskirjansa ohjaajan kysymykseen, eroaako kotivideoaineisto merkittävästi television realityohjelmista, Kantonen vastaa, että toisin kuin hauskat kotivideot, heidän videonsa sisältävät tylsiä ja ikäviäkin tapahtumia. Metodi sai alkunsa, kun taiteilija yritti miettiä mitä valtavalle videoaineistolle pitäisi tehdä ja mikä sen 
merkitys on. Kehittely jatkui Asking for Advice -performansseissa, joissa temaattisiin kategorioihin järjestettyä materiaalia esitettiin yleisöille $\mathrm{mm}$. Puolassa ja Malesiassa, tavoitteena saada neuvoja aineiston jatkokäyttöön.

Vapaamuotoisten, dialogisuuteen perustuvien katselutilanteiden aikana kerättiin kommentteja niistä otoksista, jotka katsojat itse valitsivat katsottavakseen. Menetelmän innoittajana oli cinéma véritén kehittäjiin kuuluvan Jean Rouchin idea jaetusta antropologiasta. Rouchin tapana oli esittää keskeneräisiä elokuviaan niissä esiintyville henkilöille ja ottaa heidän kommenttinsa huomioon elokuvan viimeistelyssä. Kantonen vie idean vielä pitemmälle ja rakentaa dialogisen prosessin kautta moniäänisiä videoteoksia, joissa äänensä saavat kuuluviin paitsi alkuperäisissä otoksissa esiintyneet ihmiset myös otoksia myöhemmissä vaiheissa kommentoineet katsojat.

Kantonen esittelee metodin synnyn seikkaperäisesti, jopa ihmisten kanssa käymiään keskusteluja siteeraten. Pääpiirteittäin metodin idea on seuraava: ensimmäisen sukupolven muodostaa alkuperäinen otos, toisen sukupolven otosta koskevat kommentit, kolmannen kommenttia koskevat kommentit ja niin edelleen. Menetelmää jatketaan niin kauan kuin kommentit tuottavat uusia näkökulmia aiheeseen. Uusien kommenttikierrosten sato editoidaan osaksi videota, joka saa näin yhteisöllisen luonteen.

Keskeisenä tutkimustuloksena esitetään, että uusien sukupolvien myötä keskustelu etääntyy alkuperäisestä otoksesta käsittelemään katsomiskokemusta, toisia kommentteja ja katsojien omaan arkeen liittyviä asioita. Katsomisen reflektointi viedään siis ääripisteeseen asti. Kantonen luonnehtii suhtautumistaan aineistoonsa bahtinilaisittain karnevalistiseksi, mikä tarkoittaa, että hän pyrkii osoittamaan kaiken suhteellisuuden ja muokattavuuden, sekä näyttämään, että naurettavaksi tekemisen toinen puoli on kunnioituksen osoittaminen: "I make academic comparisons that can be seen as a turning of the inside out, as bad manners and even as offensive" (s. 414). Kantosen mukaan videokuvan sukupolvittelu kommentoi hermeneuttista metodia. Se tavallaan karnevalisoi hermeneutiikan. Vuonna 2002 käynnistetyn pitkäkestoisen Tunúwame-projektin yhteydessä metodin rooli on erilainen. Siinä se toimii suunnittelun apuvälineenä ja videon taiteellinen käyttö tuo näkyvyyttä museohankkeelle.

Elokuvatutkimuksen näkökulmasta katsomisen prosessuaalisuuden korostaminen ja yhteisöllisen katsomisen menetelmän kehittäminen on tervetullutta. Kantonen kritisoi Hollywood-elokuvan kautta teoretisoitua asetelmaa, jossa katsominen mielletään hyvin yksilökeskeiseksi ja yksisuuntaiseksi. Videon sukupolvittelu nojaa Miriam Hanssenin teoretisoimaan jälkiklassiseen, performatiiviseen katsomiseen, jossa elokuva täydentyy katsojan panoksen myötä. Tällöin katsomistilanne ei ole ensisijaisesti immersiivinen, mutta eläytyminen kuvattujen ihmisten tilanteisiin on silti mahdollista. Katsomistilanne linkittyy kulttuuriseen kontekstiin tiiviimmin, siihen sisältyy häiriöiden ja katkosten mahdollisuus ja tästä kaikesta johtuen tulkintojen moninaisuus. Kantonen määrittelee katsomisen tilanteita Oscar Negtin ja Alexander Klugen (1988) termillä proletarian public sphere, mikä tarkoittaa valtarakenteista vapaata sosiaalista kokemusta. Sekä Negtin ja Klugen termiin että videokuvan sukupolvittelu -metodiin sisältyy hieman idealistinen toive olemassa olevien rakenteiden purkamisesta katsomistilanteiden ympäriltä.

Tutkimus sijoittuu myös antropologian, erityisesti alkuperäiskansojen tutkimuksen, alueelle. Keskeisin teoreettinen vaikuttaja tässä suhteessa on Jay Rubyn visuaalinen antropologia, jossa elokuva itsessään käsitetään tutkimuksen teon välineenä. Kantonen toteaa, että siinä missä Rubyn mukaan tutkijan tulisi ryhtyä tekemään elokuvaa tietyn olemassa olevan teorian lähtökohdista, videokuvan sukupolvittelussa jokainen tapaus synnyttää omat teoriansa ja tulkintansa. Kantonen kertoo, että myös katsojat osallistuvat teorian muodostukseen, mutta tätä puolta hän ei käsittele kovin analyyttisesti. Hän avaa asiaa lähinnä siteeraamalla useita ystäviensä kanssa käymiään keskusteluita, jotka vaikuttivat hänen ajattelunsa kehittymiseen.

Mitä tulee teorioihin, Kantonen sanoo haluavansa välttää yhteen positioon sitoutumista. Teoriavalinnoissa näkyy kuitenkin tietty johdonmukaisuus ja niiden käyttö on sisäistettyä, mikä on hyvä asia, sillä teorioita tutkimuksessa riittää: Bahtinin karnevalismi, Hanssenin "post-classical viewing", dialogi- 
suus eri teoreetikoiden (mm. Grant Kester) kautta tarkasteltuna, Nicholas Bourriaudin "micro-community", Rouchin jaettu antropologia ja Michael Taussigin "mimetic excess" kytkeytyvät kaikki moniäänisyyden ja -tulkintaisuuden ideaan. Yhteisötaiteensa periaatteita Kantonen määrittelee yhteiskuntafilosofisista lähtökohdista Tuija Pulkkisen ja Chantal Mouffen kautta nostaen erityisesti esiin Mouffen antagonistisen pluralismin.

\section{Itserefleksiivinen ja rönsyilevä tutkimusote}

Tärkeä osa tutkimusta on pitkän tutkimusprosessin reflektointi. Kantonen kirjoittaa pääosin minämuodossa ja liittää mukaan sitaatteja ohjaajiensa ja perheenjäsentensä kanssa käymistään keskusteluista sekä kertoo tutkimustyön konkreettisista haasteista. Kun tutkija-taiteilija tarkastelee omaa tuotantoaan, johon koko perhe on antanut panoksensa, niin lopputuloksen autobiografisuus ja yhteisöllisyys on väistämätöntä. Osan luvuista Pekka Kantonen on kirjoittanut yhdessä Lea Kantosen kanssa. Generational Filming herättää empatiaa taiteilija-tutkijan ponnisteluja kohtaan. Koska tutkija selvittää teoreettisen lähestymistapansa lisäksi taiteellisen toimintansa taustaa ja koska aineistoa on paljon, kokonaisuus paisuu suureksi ja valitettavasti myös vähän raskaaksi.

Tutkimuksen rakenne seuraa metodin kehittymistä vaihe vaiheelta. Jokainen luku pureutuu metodin vaiheisiin kuitenkin eri tapaustutkimuksen kautta. Koska tapaustutkimuksia on niin monta ja niihin jokaiseen liittyy omia erityiskysymyksiä, on kokonaisuuden hahmottaminen välillä työlästä. Keskeiset kysymykset esitellään johdannossa, mutta lukija olisi hyötynyt opastuksesta ja kertauksesta myös matkan varrella. Tunúwame, Sääti meile Säksä aigu ja Autobiography of a Friend eroavat monin tavoin kotivideoista. Niiden kautta tutkija pystyy havainnollistamaan metodin erilaisia käyttötapoja, mutta niihin liittyy myös paljon erityiskysymyksiä, jotka tekevät tutkimuksesta paikoin turhan rönsyilevän.

Pisimmän käsittelyn saa The Haircut, joka käsittelee Kantosten Pyry-pojan traumaattista hiustenleikkuukokemusta vuosina 1992 ja 2005. Yleisöltä kysytään, ovatko pojan jälkim- mäisen leikkauksen yhteydessä vuodattamat kyyneleet aitoja. Kantonen tulkitsee videota antropologian karnevalisoimisena ja vertaa sitä Jean Rouchin The Mad Masters -elokuvan (1955) tekoprosessiin ja vastaanottoon sekä teoretisoi videota jaetun antropologian, Dziga Vertovin kino-pravda-käsitteen ja Michael Taussigin mimeettisen eksessin pohjalta. Hän rinnastaa metodin käytön The Haircutin osalta myös Claude Lanzmannin Shoah-elokuvaan, sillä molemmissa menneisyyden tapahtuma rekonstruoidaan nykyhetkessä osin fiktiivisin keinoin. Näissä vertailuissa juuri on kyse karnevalisoimiselle ominaisesta asioiden suhteellistamisesta ja loukkaavuuden rajoille astumisesta. Keskustelu tekee pitkän kiertotien Rouchin elokuvan vastaanottoon ja hauka-rituaaleihin kunnes palaa tapausten välisiin yhtäläisyyksiin ja The Haircutin yleisön moraalisiin reaktioihin. Tämä on yksi kohta, jossa olisi ollut varaa tiivistää, jotta keskustelun keskeinen argumentti olisi kirkastunut paremmin.

\section{Tärkeitä eettisiä kysymyksiä}

Tutkimus tuntuu melkein elämäntyön esittelyltä. Videopäiväkirjojen analysoimisen kannalta tärkeä kotivideo-ja reality-keskustelu, yhteisötaiteen näkökulma monine käsitteineen sekä jälkiklassisen katsomisen käsite tarjoavat, ainakin elokuvatutkijan näkökulmasta, riittävästi näkökulmia yhteen väitöskirjaan. Etnografian ja yhteisötaiteen näkökulmat yhdistävät koko aineistoa, mutta yksittäisiin tapaustutkimuksiin mahtuu loputtomalta tuntuva määrä erityiskysymyksiä. Esimerkiksi keskeneräisessä Tunuwame-projektissa taiteellinen tutkimus yhdistyy alkuperäiskansojen tutkimukseen ja laajan kulttuurihankkeen edistämiseen. Projektin esittelyyn on sisällytetty Meksikon wirrarika-kansan ja saamelaisten taiteen ja kulttuurin sekä alkuperäiskansojen välisen dialogin ja oikeuksien käsittelyä.

Mitä tietoa näiden arkisten, esimerkiksi lasten torumista tai vakoiluleikkiä käsittelevien, otosten merkityssisällön pohtiminen tuottaa? Mikä menetelmän tavoite laajemmin ottaen on? Yksi menetelmän anti liittyy epistemologiaan. Johtopäätöksissä todetaan, että metodi vie kauemmas luotettavasta tiedosta eli siitä mitä otoksissa alun perin tapahtui. Se synnyttää 
enemmän kysymyksiä kuin vastauksia, eikä aseta ketään osallistujista tiedollisessa mielessä toisten yläpuolelle. Tieto ymmärretään tutkimuksessa Foucault'n mukaisesti erilaisiin valtapositioihin sitoutuneena. Tutkimus havainnollistaa esimerkiksi erilaisten kulttuuristen kontekstien vaikutusta kotivideoiden tulkitsemiseen. Käytännöllisempi anti liittyy siihen, miten metodia voi hyödyntää pitkäkestoisten projektien suunnittelussa ja toteuttamisessa.

Elokuvatutkijan näkökulmasta tutkimuksen tärkein anti liittyy metodin kehittämisen myötä esiin nouseviin kysymyksiin. Menetelmä nostaa esiin tärkeitä eettisiä kysymyksiä, kuten rajan tekemisen metodin hyödyllisen ja haitallisen käytön välille. Kantonen huomauttaa, että yleisöä voi ohjailla ja provosoida haluamiinsa suuntiin - ja myöntää itsekin tehneensä niin. Hän nostaa esiin tilanteita, joissa heidän toimintaansa kyseenalaistettiin ja pidettiin epäeettisenä. Moraalinen närkästys kohdistui usein lasten rooliin videoissa. Tutkimuksen keskeinen anti onkin elokuvatutkijan positiosta katsottuna siinä, että se nostaa esiin monia katsomisen ja elokuvanteon etiikkaan liittyviä kysymyksiä. Osallistavuus, elokuvantekemisen demokratisoiminen ja yhteisöllisempien katsomisen tapojen etsiminen ja niiden mahdollistaminen on tervetullutta ja eettisesti merkityksellistä sekä elokuvan tutkimuksen että katsomisen näkökulmasta.

\section{Kaisa Hiltunen}

FT, Taiteiden ja kulttuurin tutkimuksen laitos, Jyväskylän yliopisto 